\title{
Amantadin resistant variants of influenza $A$ virus from Flu-like infected suspects in a Children Infectious Research Center in Tehran, Iran
}

\author{
Zahra Shokati Eshkiki ${ }^{1 *}$, Fatemeh Fotouhi ${ }^{1}$, Vahideh Mazaheri ${ }^{1}$, Tina Bolurieh ${ }^{1}$, Abbas Jamali ${ }^{1}$, \\ Sedigheh Rafiee Tabatabaee ${ }^{2}$, Masoumeh Tavassoti Kheiri ${ }^{1}$
}

From Institut Pasteur International Network Annual Scientific Meeting

Hong Kong. 22-23 November 2010

The matrix protein $2\left(\mathrm{M}_{2}\right)$ blocker, Amantadin, is approved by FDA to treat and control of influenza A virus infections in children and adults. Recently, some substitutions at amino acid positions are causing the emergence of anti viral drug-resistant strains of influenza virus.

To investigate the frequency of Amantadin resistance among influenza A viruses isolated in children (up to 10 years old) referring to Children Infectious Research Center in Tehran - Iran during the 2008 - 2009 Flu season, 124 samples were collected. Forty cases from them were detected as influenza A virus by Reverse transcriptase polymerase chain reaction (RT-PCR). The Large subunit of hemagglutinin (HA1) and $\mathrm{M}_{2}$ genes were amplified by RT-PCR followed by sequencing.

$62.5 \%$ of positive cases were $0-3$ years, $10 \%$ of them were $4-6$ years, and $27.5 \%$ were $7-10$ years. The result shows $70 \%$ were male. $50 \%$ of positive cases affected sporadic. Clinical symptoms in these positive cases were as follows: Sudden onset $51 \%$, fever $69.4 \%$, headache $21.8 \%$, coryza $82.5 \%$, weakness $54.8 \%$, pharingitis $41.1 \%$, bronchodyspenia $4 \%$, cough $11.3 \%$, agitation $58 \%$, sputum $59.7 \%$, and muscle pain $8 \%$, gastrointestinal problem, $23.4 \%$, otitis $13 \% .97 .5 \%$ of these forty cases did not received influenza vaccine and $40 \%$ received antibiotic.

Our data show that Amantadin resistant $\mathrm{A} / \mathrm{H}_{3} \mathrm{~N}_{2}$ is caused by a single amino acid mutation that makes a Ser 31 Asp substitution in $M_{2}$ protein. Since these children might not used Amantadin, the drug resistance determined in this project is not related to direct usage

'Department of Virology (Influenza Unit), Pasteur Institute of Iran, Tehran

13169-43551, Iran

Full list of author information is available at the end of the article of Amantadin by the patient. Continued surveillance is required to elucidate full Amantadin-resistant pattern of influenza virus in Iranian children, especially in the recent pandemics.

\section{Author details}

'Department of Virology (Influenza Unit), Pasteur Institute of Iran, Tehran 13169-43551, Iran. ${ }^{2}$ Children Infectious Research Center, Mofid Hospital, Tehran 15514-15468, Iran.

Published: 10 January 2011

\section{doi:10.1186/1753-6561-5-S1-P63}

Cite this article as: Eshkiki et al:: Amantadin resistant variants of

influenza A virus from Flu-like infected suspects in a Children Infectious Research Center in Tehran, Iran. BMC Proceedings 2011 5(Suppl 1):P63.

Submit your next manuscript to BioMed Central and take full advantage of:

- Convenient online submission

- Thorough peer review

- No space constraints or color figure charges

- Immediate publication on acceptance

- Inclusion in PubMed, CAS, Scopus and Google Scholar

- Research which is freely available for redistribution 